\title{
New Seasonal Factors for the Adjusted Monetary Base
}

\section{R. Alton Gilbert}

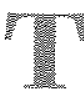
reserve requirements (CRR), which changed the timing berween deposit liabilities and required reserves, has altereo the seasonal pattems in the adjusted monetary base (AMB).' Weekly variability in the AMB has been substantially higher' since that date, which suggests that seasonal factors based on past data do not rellect the seasonal patterns in the $A M B$ under CRR:This article describes a new method of deriving seasonal factors for the AMB that reflects the timing of reserve accounting under CRR:

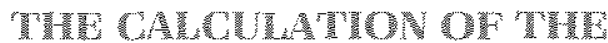

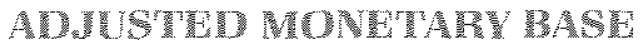

The $A M B$ is designed to be a single measure of all Federal Reserve actions, inchuding changes in reserve requirements, that influence the money stock. It is equal to the source base plus a reserve adjustment magnitude $\mathrm{RAM}$ that accounts for changes in reserve

R. Alton Gibert is an assistant vice president at the Federal Reserve Bank of St. Louis. Paul $G$. Christopher provided research assistance.

A general description of CRR appears in Gilbert and Trebing (1982).

2The average absolute value of weekly changes in the AMB from January 1982 trough fanuary 1984 was $\$ 492$ millon. This mea sure of weekly variability was $\$ 1,723$ miltion for the period February 1984 through December 1985 , more than three times larger than in the earlier period

An earlier paper by Farley (1984) presents a difterent method of deriving seasonal factors that reflect the timing of reserve accounting under CPR. requirements by the Federal Reserve.t

RAM is the difference between the reserves that would be required given current deposit liabilities/ if the base period's reserve requirements were in effect and the reserves that are actually required given current reserve requirements. Adding RAM to the source base produces a series that shows what the source base would have been in each period if reserve requirement matios had been those of the base period. This procedure converts the impact of reserve requiement changes into equivalent changes in the source base, holding reserve requirements constant."

\footnotetext{
"The following atticles describe and explain the AMB in greater detail: Gilbert (1980, 1983 and 1984) and Tatom (1980).

The source base equals the reserve balances of depository institutions with Federal Reserve Banks, which excludes their required clearing balances and balances held to compensate for float, plus total currency in circulation, whether held by depository institutions or the public. It is derived from the combined balance sheets of the Federal Reserve Banks and the U.S. Treasury.

The base period for calculating RAM is January 1976 through August 1980. Base period reserve requirements are the average reserve requirements over that period for two categories of deposit liabilities: transaction deposits and lotal time and savings deposits. For member banks, the average required reserve ratio was 12.664 percent on transaction deposits and 3.1964 percent on total time and savings deposits. For nonmember institutions, base period reserve requirements were zero, since they were not subject to reserve requirements of the Federal Reserve in the base period. Thus, RAM is calculated as the current transaction deposits of member banks multiplied by 0.12664 , plus the current total time and savings deposits of member banks multiplied by 0.031964 , minus the current required reserves of all depository institutions.
} 


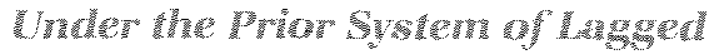 Y}

Calculation of the AMB under lagged reserve requirements (LRR) is illustrated in equations 1 through 3. Definitions of the terms in these equations are presented in table 1. Equation 1 shows how RAM is calculated for each reserve maintenance period under LRR.

$$
\text { (1) } \text { RAM }_{1}=\text { BRTR }\left(\text { TR }_{t-1}\right)+\text { BRTS }\left(T_{1-1}\right)-\text { RR }_{1}
$$

The source base is equal to total currency outstanding that held by the public and in the vaults of depository institutions plus the reserve balances of depository institutions. Under LRR, the items that could be used to meet required reserves in the current maintenance period were reserve balances held in the current period $\left\langle R_{\mathrm{k}}\right\}$ plus vault cash held in the week ending 14 days earlier $\left(V_{1-1}\right)$. This sum is thus equal to required reserves $\left(\mathrm{RR}_{1}\right)$ plus excess reseves $\left(\mathrm{E}_{1}\right)$, Conse quently, the source base can be expressed as shown in equation 2

(2) $\mathrm{SB}_{4}=\mathrm{CP}_{\mathrm{t}}+\mathrm{V}_{1}+\mathrm{RB}_{\mathrm{k}}$

$$
=\mathrm{CP}_{1}+\mathrm{V}_{1}+\mathrm{RR}_{1}+\mathrm{E}_{1}-\mathrm{V}_{2-13}
$$

Thus, the AMB under LRP is shown in equation 3.

$$
\text { (3) } \begin{aligned}
\mathrm{AMB}_{1}= & \mathrm{SB}_{1}+\mathrm{RAM}_{1} \\
= & \mathrm{CP}_{1}+\mathrm{E}_{1}+\mathrm{V}_{1}-V_{1-14}+\operatorname{BRTR}\left(\mathrm{TR}_{1+14}\right) \\
& +\mathrm{BRTS}_{\left(\mathrm{TS}_{1-14}\right)}
\end{aligned}
$$

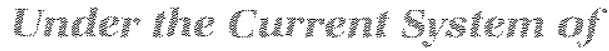

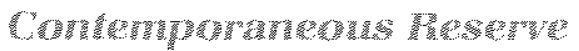

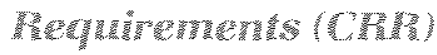

The reserve mantenance periods, during which average reserves must equal or exceed required rem serves, have been lengthened under CRR to two-week periods ending every other Wednesday. Required reserves on transaction deposits for the current twoweek maintenance period are based on daily average transaction deposits for the 14-day period ending two days before the end of the current maintenance period. In contrast, required reserves on time and sav ings deposits are based on daily average deposits over a 14-day period ending 30 days before the end of the current mantenance period. The assets of depository institutions that count toward meeting their teserves in the current maintenance period are their reserve balances in the current maintenance period plus average vault cash over the 14 dav period ending 30 days before the end of the current maintenance period. Equation 4 illustrates the calculation of the AMB un der CRR.

\section{Table 1}

\section{Definitions of Terms Used in Specifying the Adjusted Monetary Base}

$\mathrm{SB}$. The source base ovel the maintenance penod ending on tay 1

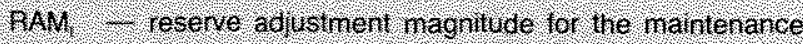
perod ending on dayl

BAlf. base period requred reserve ratio on the transaction teposis or menbel banks

If. 14 transaction cerosis of nerrber barks on he week ending 14 days before dayl

BLIS \SAse period required reserve talio on the ime and savings deposits of nember banks

15. 4 . the and savings deposits of nember banks in the week ending 14 days betore dayt

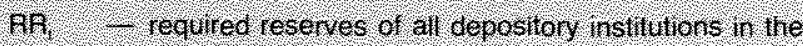
mainenarice period endrag on dart

n8, belances of depostony institutions in het reserve accounts at Federal neserve Banks in the nainte. hance period ending on day

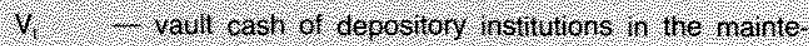
hance period enditg on dayl

V., V. vault cash or depository instivitions ht he week ending 44 days betore the end of the current naintenance period

C. . excess reserves in he mantenance pertod encing on day t prior to the mposition of reserve requirenents of he tedera Reserve on all depository institions in 1980. it inclides the vault cashor normember histiu. tions, held in the week ending 14 doys eartier

$\mathrm{CP}$. $४$ currency held by the puble to he namterance period ending or dayt

TR. S. transaction deposits of nember banks over the 14 days ending Wo days betore the end of he current maintenance perbod

T5. S. The ane savings aeposits of nember barks over the 44 days ending 30 days before the end of the curent rintenance period

Y.3. vaul cash over the 14 days ending 30 days belore the end of the curfent maintenance penod

(4) $A \mathrm{MB}_{1}=\mathrm{SB}_{1}+\mathrm{RAM}_{\mathrm{t}}$

$$
\begin{aligned}
& =C P_{2}+L_{1}+V_{1}-V_{1-3 A} \\
& + \text { BRTR }\left\{T_{t, \ldots 2}\right)+\operatorname{BRTS}\left(\mathrm{TS}_{t-3 \mathrm{st}}\right)
\end{aligned}
$$

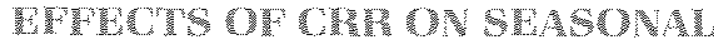

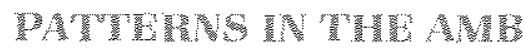

If the seasonal pattems of transaction deposits anı time and savings deposits are not changed by th 


\section{Chart 1 \\ Seasonally Adjusted Monetary Base Old and Revised Series}

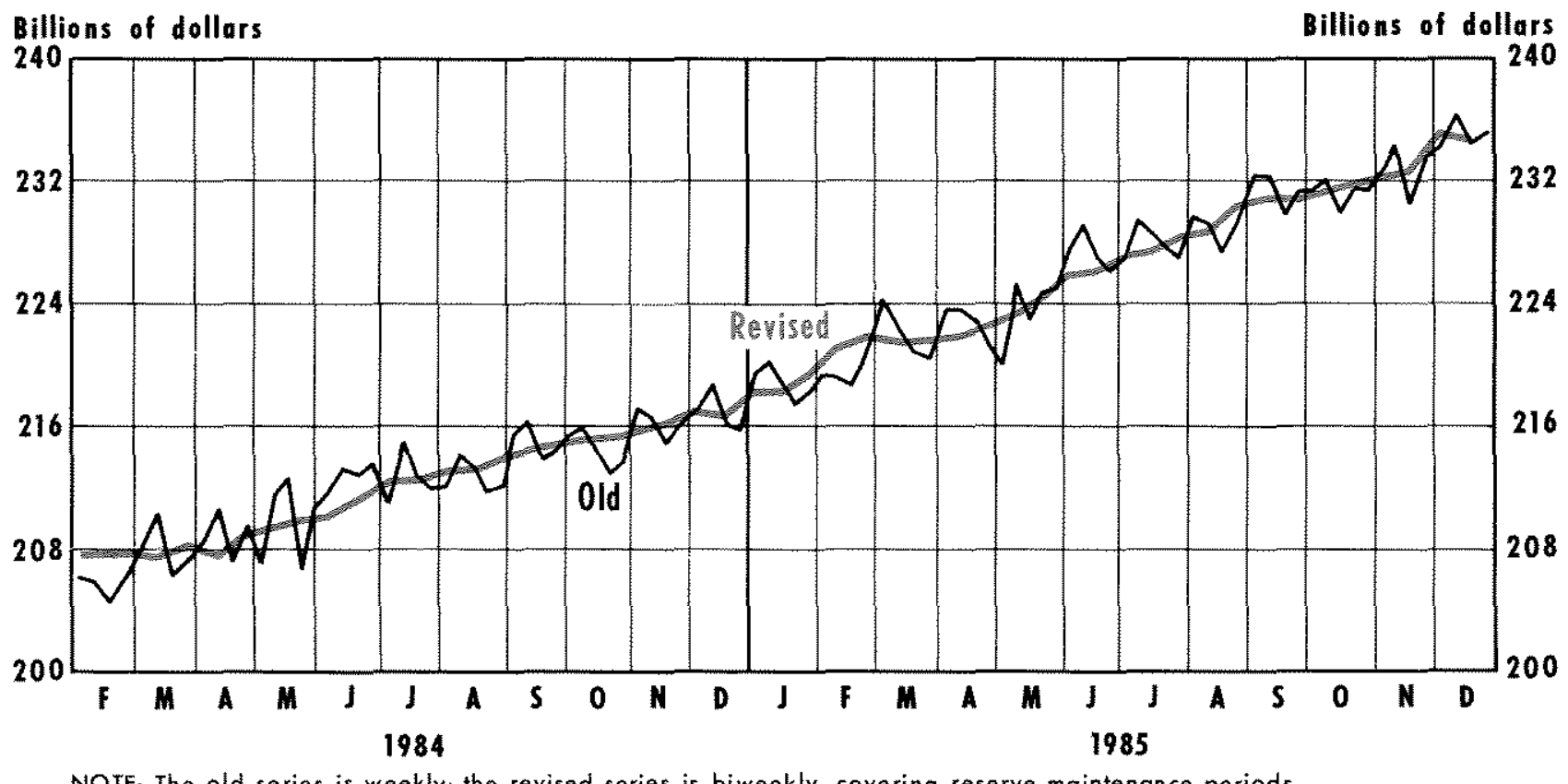

NOTE: The old series is weekly; the revised series is biweekly, covering reserve maintenance periods.

switch from LRR to CRR, seasonal movements in the AMB will be different under CRR. For example, an increase in transaction deposits will lead to a rise in the AMB about two weeks earlier under CRP than under LRR. In contrast, a rise in time and savings deposits will lead to a rise in the $A M B$ about two weeks later under CRR than under LRR.

Through 1985, seasonal factors for the AMB were derived by applying the $\mathrm{X}+11$ seasonal adjustment program to past AMB data, the bulk of which were for the period prior to February 1984. Thus, these data are generally inappropriate in calculating seasonal factors for the period since February 1984

Alternative seasonal factors for the period since February 1984, however, can be derived by a simple procedure. The procedure requires the calculation of a counterfactual AMB series for several years prion to February 1984 that reflects what the AMB's seasonal pattems would have been if CRR had been in effect

${ }^{7}$ The weekly seasonal factors tor the AMB are detived from a version of the X-1 program that has been modified by the staff of the Federal Reserve Board to derive weekly seasonal factors from monthly seasonal tactors. during the earlier period. "The counterfactual AMB series is derived by adding to the AMB (as calculated before February 1984) the adjustments necessary to convert the timing of reserve accounting to that under CRR. Equation 5 shows how this counterfactual AMB series is derived. Note that equation 5 reduces directly to equation 4 when components with opposite signs are cancelled.

$$
\begin{aligned}
& \text { (5) } A M B_{1}=\mathrm{CP}_{1}+\mathrm{E}_{3}+\left(\mathrm{V}_{\mathrm{t}}-\mathrm{V}_{\mathrm{t}-1,4}\right)
\end{aligned}
$$

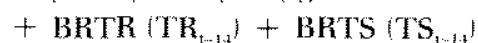

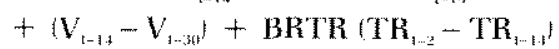

$$
\begin{aligned}
& + \text { BRTS TTS } \text { T.M0 }_{10}-\mathrm{TS}_{1-1.4}
\end{aligned}
$$

The counterfactual $\mathrm{AMB}$ series for petiods prior to February 1984 is calculated as shown in equation 5 , with one modification. The modification involves an adjustment for the change in the timing of reserve accounting on vault cash $\left(V_{1,-1,}-V_{t-34}\right)$. The term $V_{t-1,1}$ is for weeks ending on Wednesdays, whereas $V_{1,3 i}$ is for weeks ending on Mondays. The time series currently maintained on weekly vault cash is for weeks ending on Mondays, which is available back to 1975. An approximation to $\left(V_{1-1,4}-V_{t-30}\right)$ in equation 5 is derived as $\left(V_{1-\mathrm{E}}-V_{\mathrm{t} ; \mathrm{w}}\right)$, using data on the vault cash of all commercial banks from 1975. The counterfactual series on the 


\section{Chart 2}

\section{M1 Multiplier old and Revised Series}

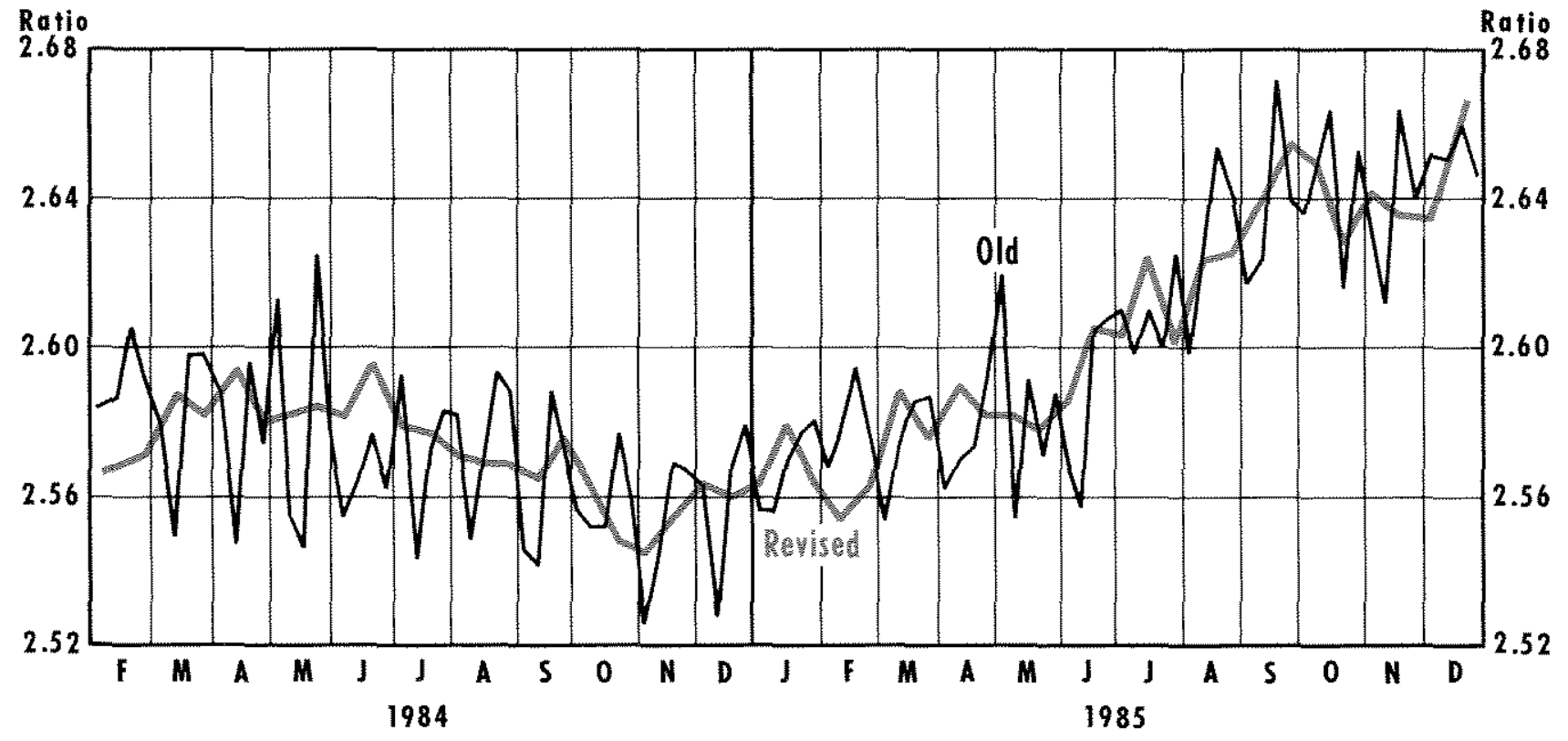

NOTE: The old series is weekly, the revised series is biweekly, covering reserve maintenance periods.

AMB does not include an adjustment for the change in the timing of reserve accounting for vaut cash in the years 1969 through 1974 . The counterfactual $\mathrm{AMB}$ series for several years prior to February 1984 is combined with the $A M B$ as calculated since February 1984. Seasonal factors ane derived from this series and applied to the AMB, not seasonally adjusted, since Februaty 1984.8

Much of the increase in short-run variability in the AMB since February 1984 is elminated by using seasonal factors based on the counterfactual series. Fu' thermore. AMB data for the two-week reserve mainte-

The counterfactual observations for the AMB in periods prior to February 1984 are calculated for weekly periods. For the purpose of calculating seasonal factors, observations on the AMB since February 1984 are calculated for each week (seven-day periods ending on Wednesdays), by adding the source base for the week to the biweekly observation for FAM that includes that week. The $X-11$ program is used to derive weekly seasonal factors from this weekly series. The weekly seasonal factors are used for calculating the biweekly observations for the AMB, seasonally adjusted, since February 1984.

Data on the transaction deposits and on time and savings deposits of member banks are available for weeks ending on Mondays since 1979. Data from 1979 through 1985 provide enough weekly nance periods are less variable than in the weekty data. Chart 1 shows the difference between weekly data on the $A M B$ as published through 1985 and the biweekly series with the new seasonal factors based on the counterfactual method. Chart 2 presents a similar contrast between the atternative M1 multipli. ers. Table 2 indicates a lower incidence of lange changes with the alternative seasonals, especially for the biweekly series.

\section{CONCUSTONS}

The weekly adjusted monetary base has been mole variable since the Federal Resenve adopted contempo. raneous reserve requirements in February 1984. The increase in its weekly variability appears to reflec: problens with estimating the seasonal patterns in the AMB using data prior to February 1984. New seasona

observations for the calculation of the weekly seasonals, bt monthty data are needed over a longer pertod to get meaningt results from the $x-11$ program. Monthly average observations $f_{c}$ the counteractual series on the $\mathrm{AMB}$ for the years 1969 throug 1978 are derived by using data on deposiss tor weeks ending o Wednesdays as approximations for observations on deposits fo weeks ending on Mondays. 


\begin{tabular}{|c|c|c|c|c|}
\hline \multicolumn{5}{|c|}{ 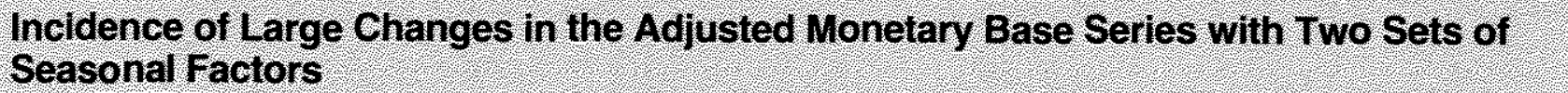 } \\
\hline & \multicolumn{2}{|c|}{$\begin{array}{l}\text { Weekly Series } \\
\text { (9a periods) }\end{array}$} & \multicolumn{2}{|c|}{$\begin{array}{l}\text { Bimeekiy Series } \\
\text { (48 periods) }\end{array}$} \\
\hline $\begin{array}{l}\text { Percentage ol periods } \\
\text { in which the absolute } \\
\text { changes of the }\end{array}$ & $\begin{array}{l}\text { Wint } \\
\text { seld } \\
\text { seasonal } \\
\text { tactors }\end{array}$ & $\begin{array}{l}\text { with } \\
\text { revised } \\
\text { seasorial } \\
\text { tactors }\end{array}$ & $\begin{array}{l}\text { Whith } \\
\text { seasorid } \\
\text { factors }\end{array}$ & $\begin{array}{l}\text { Whin } \\
\text { revised } \\
\text { seasonal } \\
\text { taotors }\end{array}$ \\
\hline $\begin{array}{l}5.6110 n \\
2 \text { bilon } \\
361110 \mathrm{n}\end{array}$ & $646 \%$ & $\begin{array}{l}48.9 \% \\
23.4\end{array}$ & $\begin{array}{l}75.0 \% \\
250 \% \\
104\end{array}$ & $\begin{array}{l}14.6 \% \\
2.1 \%\end{array}$ \\
\hline
\end{tabular}

factors have been derived from a counterfactual $\mathrm{AMB}$ series designed to reflect the timing of reserve accounting under CRR. Short-run variability in the AMB is reduced substantially by averaging the AMB over the two-week reserve maintenance periods in effect since February 1984 and by using seasonal factors derived from the counterfactual AMB series.

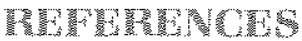

Farley, Dennis E. "Alternative Measures of the Monelary Base," paper presented al the Federal Reserve System Committee on Financial Analysis meeting, Federal Reserve Bank of Kansas City. October 15, 1984.
Gibert, R. Alton. "Calculating the Adjusted Monetary Base under Contemporaneous Reserve Requirements," this Review (Febru+ ary 1984), pp. $27-32$.

this Review (June/July 1983), pp. 16-25.

"Revision of the St. Louis Federal Reserve's Adjusted Monetary Base," this Review (December 1980), pp. 3-10.

and Michael E. Trebing. "The New System of Conternporaneous Reserve Requirements," this Review (December 1982), pp. 3-7.

Tatom, John A. "Issues in Measuring an Adjusted Monetary Base," this Review (December 1980), pp. 11-29. 